\title{
Strip-Planting Rhizoma Peanut into Grazing Systems ${ }^{1}$
}

\author{
Jose Dubeux, Lynn Sollenberger, Joao Vendramini, Marcelo Wallau, Ann Blount, Liza Garcia- \\ Jimenez, Erick Santos, and David Jaramillo²
}

\section{Introduction}

Nitrogen $(\mathrm{N})$ is one of the major off-farm inputs in livestock systems, either in the form of $\mathrm{N}$ fertilizer or purchased feed (e.g., soybean, cottonseed meal). Fortunately, you can reduce those expenses by growing your own nitrogen using forage legumes. Rhizoma perennial peanut (RPP) is a legume adapted to the Florida environment that grows well in mixtures with bahiagrass. When grown in pure stand, RPP associates with soil bacteria and fixes up to $200 \mathrm{lb} \mathrm{N} /$ acre from atmospheric nitrogen, depending on the variety (Dubeux et al. 2017). Based on the percentage of rhizoma peanut in the pasture, the added $\mathrm{N}$ in mixtures would be lower. Instead, you could expect a range from 50 to $100 \mathrm{lb}$ N/acre per year in well-established mixtures. Nitrogen fixed by the legume is recycled back to the soil via cattle excreta and plant litter, acting as a slow-release fertilizer. As a result, companion species in the mixtures, such as bahiagrass, can get the benefit of the fixed N. Rhizoma perennial peanut also has better nutritive value than bahiagrass. Typically, bahiagrass has digestibility ranging from 48 to $52 \%$ and crude protein from 8 to 12\%. Rhizoma peanut has digestibility ranging from 68 to $72 \%$ and crude protein from 15 to $18 \%$. This difference is large enough to result in a significant increase in cattle performance on rhizoma peanut.

Establishing a rhizoma peanut stand takes time. With a good management program (i.e., weed control and fertilization) and adequate soil moisture, RPP can be established in one year. Researchers currently recommend strip-planting RPP in order to reduce the cost of establishment and facilitate weed control. After establishment, well-managed RPP pastures are expected to last for more than 10 years. Integrated RPP-bahiagrass pastures will reduce $\mathrm{N}$ fertilizer inputs and enhance livestock performance, reducing production costs and minimizing environmental risks associated with $\mathrm{N}$ fertilization.

\section{Varieties and Establishment}

Many varieties and germplasm are available in Florida, but Florigraze and Ecoturf have been tested more extensively under grazing. Recent research has demonstrated better productivity with Ecoturf compared to Florigraze (Dubeux et al. 2017); therefore, researchers recommend Ecoturf if the RPP is to be used in a grazing system.

1. This document is SS-AGR-421, one of a series of the Agronomy Department, UF/IFAS Extension. Original publication date July 2018. Visit the EDIS website at http://edis.ifas.ufl.edu.

2. Jose Dubeux, associate professor, Agronomy Department, UF/IFAS North Florida Research and Education Center; Lynn Sollenberger, distinguished professor, Agronomy Department; Joao Vendramini, associate professor, forage specialist, Agronomy Department, UF/IFAS Range Cattle Research and Education Center; Marcelo Wallau, forages Extension specialist, Agronomy Department; Ann Blount, professor; Liza Garcia-Jimenez, graduate student; Erick Santos, graduate student; and David Jaramillo, graduate student, Agronomy Department, UF/IFAS NFREC; UF/IFAS Extension, Gainesville, FL 32611.

The use of trade names in this publication is solely for the purpose of providing specific information. UF/IFAS does not guarantee or warranty the products named, and references to them in this publication do not signify our approval to the exclusion of other products of suitable composition. All chemicals should be used in accordance with directions on the manufacturer's label. Use pesticides safely. Read and follow directions on the manufacturer's label.

The Institute of Food and Agricultural Sciences (IFAS) is an Equal Opportunity Institution authorized to provide research, educational information and other services

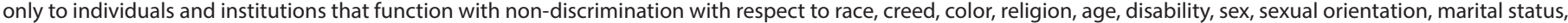
national origin, political opinions or affiliations. For more information on obtaining other UF/IFAS Extension publications, contact your county's UF/IFAS Extension office. U.S. Department of Agriculture, UF/IFAS Extension Service, University of Florida, IFAS, Florida A \& M University Cooperative Extension Program, and Boards of County Commissioners Cooperating. Nick T. Place, dean for UF/IFAS Extension. 
Rhizoma perennial peanut is vegetatively propagated, using dug rhizomes for planting material. Typically, 80 bushels of rhizomes are used to establish one acre. Rhizomes should be dug and planted within 24 hours to assure sprig viability for uniform stands. Soil moisture is critical during RPP establishment. In Florida, RPP can be planted in early spring with adequate soil moisture available. However, May is typically dry and should be avoided, unless irrigation is available. Well-drained sites are recommended for RPP establishment. Recent data indicate summer planting (June-July) is as good or better than spring planting in Florida (L. Sollenberger, personal communication). More rapid growth and more reliable rainfall are advantages of summer planting. Target soil $\mathrm{pH}$ is 6.0. Other nutrients should be applied according to UF/IFAS recommendations for RPP (http://edis.ifas.ufl.edu/ss163).

Strip-planting RPP can reduce establishment cost, because only $50 \%$ of the total area is planted. Matching the width of the RPP strip with the equipment width (e.g., spriggers, sprayers, haying equipment) is a practical option. At the UF/IFAS North Florida Research and Education Center in Marianna, researchers planted 9-ft wide RPP strips between 9 - $\mathrm{ft}$ wide bahiagrass strips. If bahiagrass pastures are already established, the existing sod must be killed with glyphosate prior to planting the RPP (Figure 1). This can be done during the previous fall; if needed, glyphosate can be reapplied prior to planting in the spring. If bahiagrass and RPP are being established at the same time, it is important to make sure soil moisture is adequate, then prepare the seedbed and plant both species in early spring. Commercial sprigging services are available because of the specialized equipment needed. Equipment for planting includes a digger and sprigger (Figure 2).

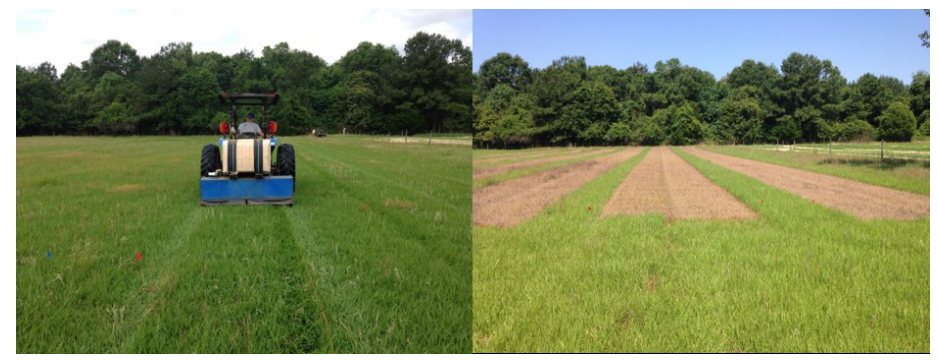

Figure 1. Glyphosate application to prepare strips prior to planting rhizoma perennial peanut.

Credits: Jose Dubeux, UF/IFAS

\section{Weed Management}

Once RPP is established, it is critical to suppress weed competition. Strip-planted RPP allows for the use of RPP-labeled herbicides while minimizing potential damage to the neighboring grass strips. Imazapic is labeled for use

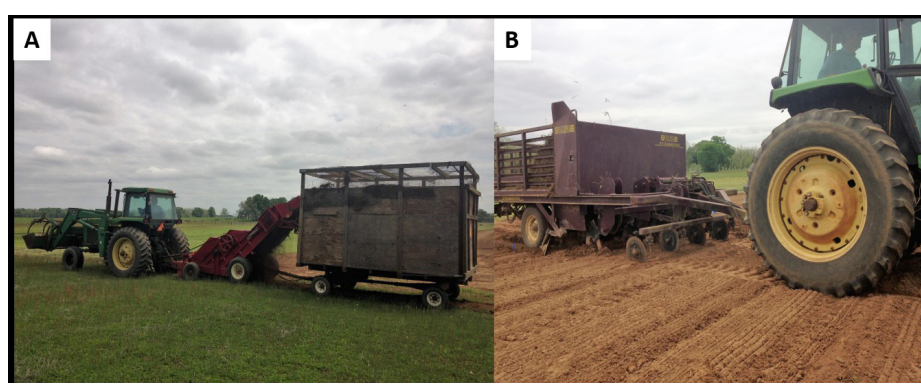

Figure 2. Rhizoma perennial peanut sprig digger (A) and sprig planter (B).

Credits: Jose Dubeux, UF/IFAS

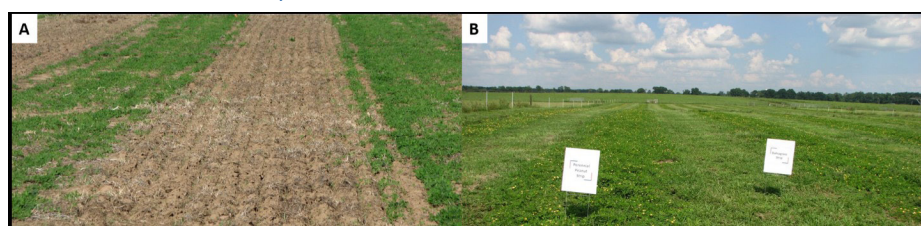

Figure 3. Strip-planting of RPP and bahiagrass during the establishment year (A) and one year after established (B). Credits: Jose Dubeux, UF/IFAS

in RPP stands in Florida and is very effective during the establishment period (Castillo et al. 2013). Imazapic should be used as a preemergent or early postemergence herbicide. The recommended rate is $4 \mathrm{fl} \mathrm{oz} /$ acre. If grass weeds are a problem, Clethodim products can also be used according to label recommendations. Recently, Gly Star Plus, a glyphosate product, was labeled for use in established perennial peanut grown for hay in Florida. Gly Star Plus can be applied during the dormant season to control winter weeds, during the growing season as a wiper application, or even broadcast if other options are not available. Gly Star Plus will severely injure bahiagrass, so it should only be used on the RPP strips. Injury will occur when used on RPP during the growing season, but the crop should recover 40 to 60 days after application. Stands during the establishment year should not be sprayed with Gly Star Plus. The complete recommendation for weed management on RPP is available at http://edis.ifas.ufl.edu/wg216. During the first establishment year of RPP, Castillo et al. (2013) observed a positive effect of $45 \mathrm{lb} \mathrm{N} /$ acre. The $\mathrm{N}$ application resulted in faster groundcover and increased RPP establishment, as long as weeds were adequately controlled.

\section{Grazing Management}

Ecoturf perennial peanut is tolerant to grazing. Researchers continuously stocked pastures with variable stocking rates for three years $(2015,2016$, and 2017), and the stripplanted RPP performed well. Results from three years of grazing indicate the possibility to replace $100 \mathrm{lb}$ N/acre by strip-planting RPP and maintain the productivity. Average stocking rate was lower for the bahiagrass-RPP mixtures compared to $\mathrm{N}$-fertilized bahiagrass pastures; however, the 
average daily gain (ADG) was significantly greater for BGRPP pastures (Table 1). These results indicate that BG-RPP pastures could also be an option for heifer development grazing systems, especially in combination with overseeded cool-season forages.

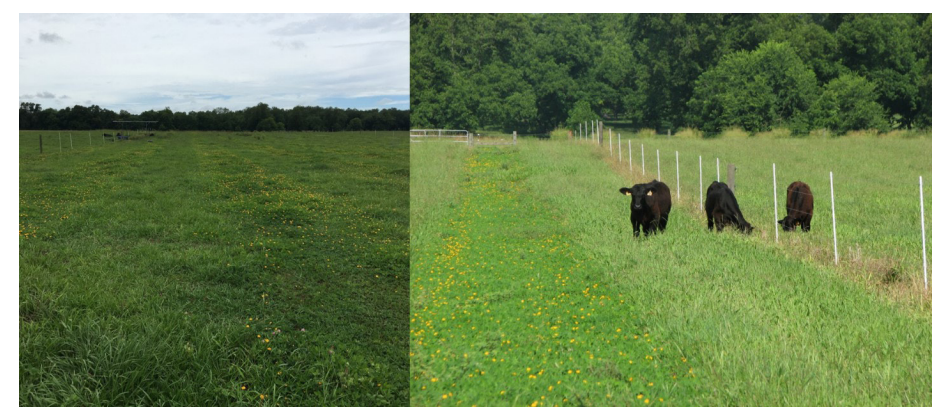

Figure 4. Established strip-planted Ecoturf rhizoma perennial peanutArgentine bahiagrass pastures under grazing at UF/IFAS NFREC in Marianna, FL.

Credits: Jose Dubeux, UF/IFAS

\section{Cost-Share Program}

NRCS established a cost-share program to strip-plant rhizoma peanut on bahiagrass pastures. For more information, contact your NRCS representative in your county.

\section{Conclusion}

Integrating rhizoma perennial peanut into grazing systems can reduce nitrogen fertilization requirements and feed supplementation during the warm season. Strip-planting is a viable option to reduce rhizoma peanut establishment cost compared to an RPP monoculture. Additionally, stripplanting helps to facilitate weed management, compared to sprigging into a living grass stand. In this study, overseeding warm-season grass-legume pastures with a blend of cool-season grass-legume mixtures extended the grazing season and resulted in livestock performance equivalent to that of $\mathrm{N}$-fertilized grass systems. Minimizing $\mathrm{N}$ fertilizer inputs reduces not only ranch production costs, but also some of the environmental problems related to the use of $\mathrm{N}$ fertilizers.

\section{References}

Castillo, M. S., L. E. Sollenberger, J. A. Ferrell, A. R. Blount, M. J. Williams, and C. L. Mackowiak. 2013. "Strategies to control competition to strip-planted legume in a warmseason grass pasture." Crop Science 53: 2255-2263.

Dubeux, J. C. B., Jr., A. R. S. Blount, C. Mackowiak, E. R. S. Santos, J. D. Pereira Neto, U. Riveros, L. Garcia, D. M. Jaramillo, and M. Ruiz-Moreno. 2017. "Biological N2 fixation, belowground responses, and forage potential of rhizoma peanut cultivars." Crop Science 57: 1027-1038. 
Table 1. Livestock performance on unfertilized bahiagrass pastures (BG), bahiagrass fertilized with $100 \mathrm{lb}$ N/acre (BGN), and bahiagrass-rhizoma peanut pastures (BG-RPP) in Marianna, FL; average of three grazing seasons.

\begin{tabular}{|c|c|c|c|}
\hline Treatment & Stocking Rate (steer/acre) & ADG (lb/steer/d) & Gain per Area (Ib/acre/season)* \\
\hline BG & $1.6 \mathrm{~b}$ & $\mathbf{0 . 6 8} \mathrm{b}$ & $125 \mathrm{~b}$ \\
\hline BGN & $1.8 \mathrm{a}$ & $0.77 \mathrm{~b}$ & $152 \mathrm{ab}$ \\
\hline BG-RPP & $1.4 \mathrm{c}$ & $1.23 \mathrm{a}$ & $220 \mathrm{a}$ \\
\hline Standard Error & 0.04 & 0.15 & 35 \\
\hline
\end{tabular}

*Averages of three years of the trial. 2015: 84 days, 2016: 168 days, and 2017: 147 days.

Means (LSMEANS) followed by the same letter within each column are not different according to the PDIFF procedure from SAS (P > 0.05). 